\title{
Henry A. Wallace's Turn Toward the New Deal, \\ 1921-1924
}

\author{
RICHARD S. KIRKENDALL
}

As Secrețary of Agriculture in Franklin D. Roosevelt's New Deal of the 1930s, Henry A. Wallace supplied leadership in the development of a new and large role for the federal government in the operations of the American agricultural system. That expansion of government was the main feature of the New Deal for agriculture. These facts are well known. Less clear in the major accounts of Wallace's life are when and why he reached the conclusion that Washington should exert great influence on farm production and commodity prices. ${ }^{1}$ A close look at his intellectual development indicates that his first three years as editor of Wallaces' Farmer were crucial in the development of his thinking in this area. It was then that he moved from rejection to acceptance of large-scale federal involvement in the agricultural system. In those years his conception of his responsibilities to one segment of the farm population, his sense of crisis, the frustration of his efforts to end the crisis through voluntary means, and the influence of his father affected the movement of his thought.

Henry A. Wallace became editor of Wallaces' Farmer in March 1921, following the departure of his father, Henry C., to

I am grateful for help from Loren N. Horton of the State Historical Society of Iowa; Glenda Riley of the Universisty of Northern Iowa; members of a discussion club in the Iowa State University history department, especially Alan I Marcus, Robert E. Scofield, Hamilton Cravens, and Richard Lowitt; the Graduate School of Iowa State University; and the Wallace Fund of the Iowa State University Foundation.

1. Russell Lord, The Wallaces of Iowa (Boston, 1947); Edward L. Schapsmeier and Frederick H. Schapsmeier, Henry A. Wallace of lowa: The Agrarian Years (Ames, 1968). 
Washington to serve as secretary of agriculture. Although only in his early thirties, H. A. had already gained considerable prestige. His pioneering work on farm prices had brought him to the attention of many people in farm circles. Published in Wallaces' Farmer and a 1920 book, Agricultural Prices, his findings suggested that price statistics were very important to farmers, that farm prices were too low relative to other prices, that this threatened all industries and all people, not just farmers, and that a new price-making system should be adopted. His work had not persuaded him, however, that government should set farm prices. $^{2}$

Wallace's conception of the proper level of farm prices and its importance for nonfarmers represented a point of view that historians and others have labeled agrarianism or agricultural fundamentalism. This is the "conviction that agriculture is par excellence the fundamental industry, and that farmers are, in a peculiar sense and degree, of basic importance in society." Agrarians regarded agriculture and rural life as basic to American welfare economically, politically, and socially. Summarizing this philosophy in the language of the time, President Theodore Roosevelt and his Country Life Commission contended early in the century,

Upon the development of this distinctively rural civilization rests ultimately our ability, by methods of farming requiring the highest intelligence, to continue to feed and clothe the hungry nations; to supply the city with fresh blood, clean bodies, and clear brains that can endure the terrific strain of modern life; and to preserve a race of men in the open country that in the future as in the past, will be the stay and strength of the nation in time of war, and its guiding and controlling spirit in time of peace. ${ }^{3}$

2. James H. Shideler, Farm Crisis, 1919-1923 (Berkeley, 1957), 198-99; Joel P. Kunze, "The Early Political Economy of Henry A. Wallace" (unpublished paper in author's possession).

3. Joseph S. Davis, "Agricultural Fundamentalism," in O. R. Jesness, ed., Readings in Agricultural Policy (Philadelphia, 1949), 5; Gilbert C. Fite, "The Historic Development of Agricultural Fundamentalism in the Nineteenth Century," Journal of Farm Economics 44 (1962), 1203-11; Wayne D. Rasmussen, ed., Agriculture in the United States: A Documentary History (New York, 1975), 1863-64, 1870. 
Agrarianism was part of H. A.'s inheritance. His grandfather, "Uncle Henry," "the founder of the illustrious Iowa Wallace family," the first editor of Wallaces' Farmer, and a member of the Country Life Commission, was "simultaneously a nostalgic agrarian and an advocate of scientific agriculture." H. A.'s father, Henry C., also shared the agrarian philosophy and handed it down to his son. As editor of Wallaces' Farmer, H. A. expressed the agrarianism that his grandfather and father also voiced. ${ }^{4}$

Yet agrarian values were not the only major component of H. A.'s thought. His perception of realities nearly overwhelmed his agrarianism, persuading him that the economic system could not be totally reshaped to conform to his view of rural values, however desirable that might be. In an attempt to be realistic, he would advise farmers to accept and imitate, rather than reject and attack, some important urban patterns of thought and behavior. $^{5}$

As an AGRARIAN AND A FARM EDITOR, Wallace felt a strong sense of responsibility to farmers, but it did not extend with equal strength to all of them. He viewed farmers as divided into superior and inferior groups, with his readers in the superior category in the region served by Wallaces' Farmer. "We cover Iowa, northern Missouri, central Illinois, eastern Nebraska, and a small part of northeastern Kansas," the journal reported to the authors of a textbook on agricultural journalism. Within that region, Wallaces' Farmer appealed, according to its own definition, "to the conservative type of farmer." Owners of good farms with no mortgages or only small ones, the paper explained in 1921, "make up about 35 percent of the farmers of the corn belt. They

4. David D. Danbom, The Resisted Revolution: Urban America and the Industrialization of Agriculture, 1900-1930 (Ames, 1979), 43; Donald L. Winters, Henry Cantwell Wallace as Secretary of Agriculture, 1921-1924 (Urbana, Ill., 1970), 297; Richard S. Kirkendall, "The Mind of a Farm Leader," Annals of Iowa 47 (Fall 1983), 138. On Wallace's agrarianism in the 1920s, see also Don S. Kirschner, "Henry A. Wallace as Farm Editor," American Quarterly 17 (Summer 1965), 187-202.

5. Two essays supplied especially helpful insights concerning the intellectual problem that Wallace faced: Richard Hofstadter, The Age of Reform (New York, 1955), especially pp. 109-30, and David W. Noble, “American Studies and the Burden of Frederick Jackson Turner: The Case of Henry Nash Smith and Richard Hofstadter," The Journal of American Culture 4 (Winter 1981), 34-45. 
feel at times that they are just as much business men as the people in the cities. ... They are the conservatives." Landowning farmers, the publication proclaimed, "make up the great conservative force of the body politic." 6

Wallaces' Farmer did not identify with what it called "radical farmers." Some of these "radicals," according to H. A.'s analysis, owned unencumbered farms but ones that had poor land or were small, less than 140 acres. Others owned larger farms that were heavily mortgaged; still others were tenants. "In times like these," Wallaces' Farmer explained, "many of these men are pushed perilously close to bankruptcy, and they naturally turn toward such schemes as governmnent ownership of railroads, currency reforms, etc." H. A. clearly opposed "radicals who have been connected with farmer-labor movements" and applauded policies that prevented them from gaining support. He warned "the big bankers of the east" that "demogogs [sic] and yellow farm papers mislead the farmers, offering as cures nostrums which can do no good whatsoever." The best farmers, he believed, had "remained true to the old ways of thinking and acting," but he feared that "another winter of low prices will make radicals of many of these men." 7

Wallaces' Farmer identified with the substantial commercial farm family of the type that joined the new Farm Bureau. Before $H$. A. took over as editor, the publication had applauded the formation of the Iowa Farm Bureau Federation in 1918 and the American Farm Bureau Federation (AFBF) two years later. In fact, H. C. had participated significantly in these developments. " "The federation," he insisted at an AFBF meeting, "must be made the most powerful business institution in the country." James R. Howard of Marshalltown, the president of both the Iowa and the American farm bureaus in their early years, re-

6. Nelson Antrim Crawford and Charles Eakins Rogers, Agricultural Journalism (New York, 1926), 278; Wallaces' Farmer, 27 April 1923, 12 August 1921, 6 January, 31 March 1922.

7. Wallaces' Farmer, 12 August 1921, 3 February, 1 September 1922.

8. Grant McConnell, The Decline of Agrarian Democracy (Berkeley, 1953), 56; Christina McFayden Campbell, The Farm Bureau and the New Deal (Urbana, Ill., 1962), 26-27; D. B. Groves and Kenneth Thatcher, The First Fifty: History of Farm Bureau in Iowa (Lake Mills, Iowa, 1968), 46; Robert P. Howard, James $R$. Howard and the Farm Bureau (Ames, 1983), 82, 106, 205; Wallaces' Farmer, 22 December 1922; Shideler, Farm Crisis, 123. 
garded Wallace as "the best of the farm paper men," and the AFBF supported his nomination as secretary of agriculture. In that office, Wallace, in turn, maintained good relations with the Iowa and national organizations. ${ }^{9}$

As editor of Wallaces' Farmer, H. A. preserved the paper's good relations with the Farm Bureau. ${ }^{10}$ Although not uncritical, he often defended it against its foes, insisting that "if the farmers of the corn belt are going to get economic justice they must maintain this organization and make it strong." Pointing out that it was being criticized both as "a radical menace to business" and as having "gone over to Big Biz," he suggested that such complaints were "the usual reward of any organization that tries to steer a sane and constructive course."11

Wallace not only defended the Farm Bureau but also opposed its chief rival, the Iowa Farmers Union, and its fiery president, Milo Reno. A foe of the bureau and its allies, the county agents, Reno looked upon the Wallaces as too close to bankers, packers, and the like. A critic of similar persuasion complained of the paper's "misplaced hopes" in the Farm Bureau. ${ }^{12}$

The new farm organization figured in the old animosity between Wallaces' Farmer and the Iowa Homestead. Based in Des Moines as was its competitor, the Homestead also enjoyed considerable prestige. Both papers were aimed at the Corn Belt, and the rivalry was so bitter that Wallaces' Farmer dubbed the other paper the "Iowa Hatestead." ${ }^{13}$ Although the Homestead initially

9. Howard, Howard, 92, 120, 139; Winters, Wallace, 53, 136-40; Henry C. Wallace to Charles E. Hearst, 21 January, 27 March, 16 May, 11 September 1924, Hearst Papers, University of Northern Iowa Library.

10. Secretary, Iowa Farm Bureau Federation to Hearst, 29 January 1925; Ferguson to Hearst, 15 March 1925, 19 January 1926; Thomas E. Johnson to Hearst, 13 December 1926, reply, 20 December 1926, Hearst Papers; Donald R. Murphy to Wallace, 27 June 1924; C. V. Gregory to Wallace, 25 May 1925, Wallace Papers, University of Iowa Libraries.

11. Wallaces' Farmer, 16 September, 30 December 1921, 6 January, 21 July, 22 December 1922, 12 January, 16 February 1923.

12. Theodore Saloutos and John D. Hicks, Agricultural Discontent in the Middle West, 1900-1939 (Madison, 1951), 212, 229-31, 282; Lord, Wallaces, 182; Winters, Wallace, 122; W. R. Bayless to editor, 21 January 1925, Wallace Papers.

13. Crawford and Rogers, Agricultural Journalism, 271; Howard, Howard, 82, 84-85; James F. Evans, Prairie Farmer and WLS: The Burridge D. Butler Years (Urbana, Ill., 1969), 87; Henry A. Wallace, Oral History, Columbia University, 159-60; Lord, Wallaces, 114-16, 129-31; Donald R. Murphy to Henry A. 
approved of the Iowa Farm Bureau Federation, the paper quickly became a leading critic of that organization and of the American Farm Bureau Federation as well. Dante M. Pierce, the Homestead's publisher, preferred the organization's major rivals, the Non-Partisan League and the Farmers Union. H. A. defended the Farm Bureau against the Homestead's attacks, calling them "irresponsible journalism," and warning against "any farm paper" that was "seeking to inflict a mortal wound on the most helpful farm organization that has yet arisen. ${ }^{114}$

The ECONOMIC PRESSURES of the early 1920s on Farm Bureau-type farmers deeply troubled Wallace. Farm prices had fallen sharply in the summer before he became editor and remained low when he took over. ${ }^{15}$ He sought to give his readers a clear understanding of the situation. In keeping with one of his intellectual habits, he quantified the crisis. He offered his readers not only statistics on the drop in farm prices but also numbers on the relationships between those prices and other realities, such as the cost of farm production and the cost of living, corporate income, the wages of city workers, and prices and wages before the war. He noted, for example, that in 1920 wages were 189 percent of prewar earnings, while farm prices were only 110 percent. By the spring of 1922 , he observed, the farm price level was only 40 percent above the level of 1910, while mortgages were up well over 100 percent. And early in 1923 he reported that the farmer's dollar bought only 65 percent as much as it had in 1914. This comparative approach was basic to Wallace's perception of the crisis. The comparisons meant that the crisis was more than low prices for farm products. ${ }^{16}$

Wallace also offered historical perspective, comparing the farmers' plight with farm situations in the late nineteenth century and in the prewar years, and he also assessed future pros-

Wallace, 27 June 1924, Wallace Papers; K. R. Marvin, "Agricultural Journalism in Iowa," in A Century of Farming in Iowa, 1846-1946 (Ames, 1946), 268.

14. Howard, Howard, 82, 84, 140, 190, 206; Wallaces' Farmer, 16 September, 4 November 1921; Saloutos and Hicks, Agricultural Discontent, 190, 212, 282.

15. On the crisis, see Shideler, Farm Crisis; on Wallace's sensitivity to it, see Wallace, Oral History, 120-22.

16. Wallaces' Farmer, 22, 29 April, 27 May, 21 October, 11 November 1921, 4 April, 1, 15 September 1922, 12 January 1923. 
pects for farmers. By late 1921, he claimed, the farm situation was worse than at any time since 1896; and farmers would find it much more difficult, he predicted, to enjoy economic success from 1921 to 1941 than they had from 1896 to 1916. The next year and the year after, he projected depressed conditions for farmers into the 1930s, possibly the $1940 \mathrm{~s} .{ }^{17}$

As an agrarian, Wallace believed that the farm crisis harmed the entire nation. Here, he emphasized two themes, one economic, the other political. From the economic perspective he stressed the importance of farm purchasing power, suggesting, for example, that city workers could not expect that the prosperity they enjoyed in 1923 would continue, for lasting prosperity depended on the ability of farm people to buy the goods that city workers produced. Pursuing the political theme, he portrayed farmers as an essential "conservative force," but prophesied that if the farm crisis persisted, agrarian radicalism would grow. ${ }^{18}$ In both cases farmers were fundamental in their importance for the United States.

Wallace obviously believed that he faced a major event, one with large implications for the Corn Belt and the entire nation. Thus, the farm crisis had to be explained. Wallace's explanation included emphases on the power of certain urban groups and the enormous productivity of Corn Belt farmers. He refused to join the "radicals" who heaped all of the blame on "Big Business," yet he did see large eastern bankers, the Federal Reserve system, and some giant corporations as contributors to the problem. ${ }^{19}$

While radicals called for a farmer-labor alliance, Wallace expressed at least as much concern about the power of organized labor as he did about the power of organized business. He insisted that high wages helped to produce and prolong the farm crisis. In his view, labor was strong and high wages were a result of that strength. The wages paid to workers on the railroads and in the

17. Ibid., 22 July, 16 September, 18 November 1921, 12 May, 27 October 1922, 20 July, 31 August 1923; Wallace to E. T. Meredith, 26 December 1923. Wallace Papers.

18. Wallaces' Farmer, 25 November, 2 December 1921, 6 January, 1, 15 September 1922, 24 August 1923.

19. Ibid., 10 June, 5 August, 9 September, 21 October, 11 November 1921, 5 January 1923. 
processing plants took much of the money that consumers spent on food, leaving little for the farmer; and the money paid to many workers forced farmers to spend too much for the goods they needed to buy. He was especially critical of the wages paid to railroad workers, the demands for more made by their unions, and their use of the strike weapon to enforce their demands. He regarded labor costs as the chief explanation for high freight rates. ${ }^{20}$

In Wallace's view, Iowa farmers contributed to their own difficulties by producing too much corn. Overproduction, he believed, was "the main reason" prices were "so unreasonably low. ${ }^{21}$ Having expanded production to meet wartime demands, corn farmers now grew much more than they had before the war. While union workers demanded shorter hours and deprived their employers of their labor when their demands were not met, and while manufacturers reduced their output to maintain prices, farmers continued to produce at high levels, working hard and often using the latest technologies. The weather cooperated, resulting in good corn yields from 1919 to $1922 .{ }^{22}$

European weaknesses were the other side of the coin. Europeans continued to buy American farm products, he argued, but did so only because prices were low. Europe, Wallace argued, was "down and out" or "bankrupt" and likely to remain so for a generation or more. Thus, Europeans could not pay "cost of production" for American farm products. ${ }^{23}$ The main cause of low farm prices, he argued late in 1922, was "the fact that we have a larger surplus of farm products for Europe to buy than before the war, whereas Europe has an immensely weaker purchasing power than was the case before the war." From 1900 to 1914 "the farming people of the middle west enjoyed the greatest prosperity that any large class of farming people ever enjoyed anywhere," he maintained. They did so because cities and effective demand in them expanded in both the United States and Europe. Now, however, according to his analysis, demand re-

20. Ibid., 24 June, 26 August, 9 September, 28 October 1921, 20 January, 28 July, 18, 25 August, 1 September 1922, 24, 28 September 1923.

21. Ibid., 5 January 1923.

22. Ibid., 25 March, 18 November, 23 December 1921, 18 August, 17 November 1922, 5 January, 6 July 1923.

23. Ibid., 11 November 1921, 3, 10, 17 February, 3 November 1922, 9, 16 February, 6 July, 7 September 1923. 
mained effective in the United States but not in Europe, and, unless wise policies were initiated, real prosperity would not return to the farm until the American urban population became large enough to buy what Europe had bought. ${ }^{24}$

What could be done? Farmers could be patient and wait for migration to the city to solve the problem. Wallace noted that many farmers and farm laborers were moving to cities as a result of the crisis, and he did favor migration by "marginal farmers" those who did not prefer farm to city life and seemed incapable of succeeding on the farm in the current situation. He may have hoped that the migration of marginal farmers would weaken the forces of agrarian radicalism by removing them from its ranks. The migration remedy, however, seemed slow and painful, made doubly so by a tendency of poor farmers to hold on to their land with "grim determination." ${ }^{25}$ On the other hand, revolutionary change to a new social order, socialistic in nature, that some advocated seemed unnecessary and unrealistic. ${ }^{26}$ Instead, he offered a capitalistic solution for the crisis in the operations of the capitalistic system.

Wallace Rejected the ARGUMENT that the way to solve the farm crisis was to raise wages paid to urban labor so that workers could buy more farm products. He argued that individuals could spend only so much on food and would use increased income for other purposes. A high level of urban employment was important to farmers, but higher wages could force employers to cut the work force. ${ }^{27}$

When his quest for a solution to the farm problem drew his attention to urban America, Wallace called for cuts in several areas and expansion in others. He advocated cuts in the wages of some workers, especially railroad workers, in freight rates, and in interest rates, and expansion of the money supply and of industrial production and employment. These were all pleas for voluntary action by various economic groups, not demands that

24. Ibid., 24 November, 1 December 1922.

25. Ibid., 18, 25 November 1921, 20 January 1922, 9 February, 13 April, 18 May, 23 July, 31 August, 7 September 1923.

26. Ibid., 9 February, 2 March, 17 August 1923.

27. Ibid., 19 May, 23 June 1922, 1 June 1923. 
Congress force unions, financiers, and industrialists to behave in these ways. ${ }^{28}$

As for the European market, Wallace did not press for efforts to strengthen it. Early in 1922 he did express concern to his father as well as to his readers regarding the high protective tariff, suggesting that Europeans needed to be able to sell manufactured goods in the American market if they were to pay adequate prices for American food, but this embarrassed his father and generated some tension between father and son, for it challenged the Harding administration's tariff policy, so $\mathrm{H}$. A. backed off. ${ }^{29}$

Instead, Wallace called for sharp cuts in corn production. Although not the only advocate of such a program, he was surely the most prominent one in the Middle West. Wallaces' Farmer had begun to offer such advice in 1919, and H. A. campaigned for it in 1921 and 1922. ${ }^{30}$ "Less corn, less work, more money" was the campaign's slogan in 1921. For 1922 it was "More clover, less corn and more money," advice that did not challenge the farmer's belief in hard work and indicated that the scheme would improve the soil as well as the profit-and-loss ledger. ${ }^{31}$ Calling for reductions as high as 25 percent, he suggested that the goal should be farm prices that were 50 percent higher in 1923 than in 1922 and eventually at least 60 percent above the prewar level and "up to a parity with the products of city labor." He promised to continue to recommend cutbacks until corn prices were within five cents of the cost of production, but not beyond that point. "The immediate objective of farmers," he proposed, "should be to recover the purchasing power which they had back in 1913 and 1914." ${ }^{32}$

28. Ibid., 15, 22 April, 24, 30 June, 19, 26 August, 9 September, 20 October, 11, 18 November, 23, 30 December 1921, 27 January, 30 June, 28 July 1922, 5 January, 2 March, 18 May 1923.

29. Winters, Wallace, 98-99, 150, 297; Schapsmeiers, Wallace, 60-61, 67; Wallaces' Farmer, 24 November 1922, 24 September 1923.

30. Schapsmeiers, Wallace, 63, 68, 86-87, 91-92; Gilbert C. Fite, George N. Peek and the Fight for Farm Parity (Norman, Okla., 1954), 131-32; Shideler, Farm Crisis, 86; Wallaces' Farmer, 18, 25 March, 8 April, 13 May, 21 October 1921, 12 January 1923.

31. Wallaces' Farmer, 8 April, 16, 23 September, 25 November 1921.

32. Ibid., 11, 24 November 1921, 7 April, 1 September, 24 November, 1 December 1922, 30 March 1923. 
Wallace was calling for economic withdrawal from Europe. He wanted farmers to serve their "principal market," the "home market. ${ }^{\prime 33}$ Thus, farmers should cut their production of export crops, receive protection from the tariff in the domestic market, and expand production only as the urban population grew. ${ }^{34}$

Wallace was not recommending that farmers push aside modern methods of farming. In fact, he participated at the same time in programs designed to increase yields, including experiments with hybrid corn. ${ }^{35} \mathrm{He}$ appeared to see no conflict between those efforts and the simultaneous ones to cut corn production. Rather than recommend a return to old, less productive methods, he advocated changes in the cropping decisions that farmers made. He advised farmers to shift some of their acres out of corn and into clover, oats, pasture, alfalfa, and a new crop for Iowa, soybeans. ${ }^{36}$ He must have assumed that when the experiments with hybridization produced results on the farms, farmers would make additional cuts in the acres they devoted to corn.

The campaign held up particular patterns of urban behavior as worthy of imitation. Industrial giants cut production when faced with deflationary pressures; labor unions pressed for shorter hours and conducted strikes. Now farmers should behave in similar ways. He saw corporate behavior as an especially attractive model; yet he also made use of the union analogy.

Farmers have just as much right to organize to control their output as union labor has to organize for the purpose of shortening hours and increasing wages. They have as much right to cease production wholly or in part as union labor has to strike. It is no more wrong for farmers to reduce production when prices are below cost of production than it is for the United States Steel Corpora-

33. Ibid., 17 February, 17, 31 March 1922. J. Samuel Walker, Henry A. Wallace and American Foreign Policy (Westport, Conn., 1976), 11-14, calls attention to Wallace's isolationist interlude.

34. Wallaces' Farmer, 8, 29 September, 3 November 1922, 9 February, 1 June, 27 July, 31 August 1923.

35. For a survey of his role, see William L. Brown, "H. A. Wallace and the Development of Hybrid Corn," Annals of lowa 47 (Fall 1983), 167-79, with comments by Alan I Marcus, 180-89, and Peter A. Peterson, 190-94.

36. Wallaces' Farmer, 12 August 1921, 6 January, 17 March 1922; Wallace to Thomas N. Hadden, 19 February 1925, Wallace to George S. Carter, 29 April 1925, Wallace Papers. 
tion to cut pig iron production in half when prices are rapidly falling. ${ }^{37}$

It would be better, he assumed, if industrialists and unions would imitate farmers by increasing production and lowering costs and prices, but, as that seemed unlikely, farmers must cut back. ${ }^{38}$ America would be a better place, he implied, if agrarian values reigned, but since power arrangements dictated that they could not, farmers must accept and conform to urban norms.

Again, Wallace did not call for government action. Instead, he tried to persuade farmers to reduce their acreage voluntarily. That method would later seem to be naive, even to him as well as others, but that was after he had tried it. Now, he called for campaigns "organized after the fashion of Liberty bond drives." Quotas would be worked out for each Corn Belt state and county; each farmer would voluntarily sign a statement agreeing to a specified cut, and the pressure of public opinion would encourage farmers to live up to their promises. ${ }^{39}$

Better economic information and organization were also essential in Wallace's solution to the farm crisis. In providing the first, public institutions must help. Corporations had the resources required to serve their needs for information, but individual farmers did not. Thus, he applauded the establishment of the Bureau of Agricultural Economics in 1922, praised Iowa State College for its work in agricultural economics, and criticized other state colleges for ignoring the marketing side of the farmer's life. ${ }^{40}$

Better organization must supplement better information. H. A. recognized that farmers were not as well organized for the task as United States Steel was, but, rather than advocate the breaking up of giant corporations, he encouraged farmers to organize and "beat capital and labor at their own game." He believed that all farm organizations must support the campaign for

37. Wallaces' Farmer, 12 January 1923. See also ibid., 10 June, 29 July, 9 September 1921, 6 January 1922. 1923.

38. Ibid., 21 October 1921, 6 January, 30 June 1922, 5 January, 2 February

39. Ibid., 8 April, 22 July, 25 November, 2 December 1921.

40. Ibid., 8, 15, 22 April, 2 December 1921, 3 March, 14 July, 25 August 1922, 6 April 1923. 
higher farm prices and that the Farm Bureau was "best fitted" to supply leadership, for it represented "more truly the sentiment of the rank and file of the actual dirt farmers." During 1921 and 1922 he appealed to farm organizations for action, not to governments. ${ }^{41}$

In 1933 Wallace would return to this emphasis on scaling down agricultural production, but then he would rely on powers of the national government-its taxing and spending powers-to accomplish this purpose. Before he could endorse such means, however, he would need to develop a more positive attitude toward large-scale government participation in the agricultural system. The inadequate results of the voluntary method would contribute to that change.

The CONSEQUENCES of the voluntary crop reduction campaign of the early 1920s disappointed Wallace. He had, after all, called for a sharp break with Iowa's agricultural past, which featured the expansion of agricultural production. Not surprisingly, he encountered considerable opposition, especially in 1921, much of it from farm organizations, farm journals, and farmers as well as business people. Some of it came from the grain trade, which wished to handle a large volume of corn and warned of shortages. Clifford Gregory, the editor of the Chicago-based Prairie Farmer, and some of the farm organizations, above all the Iowa Farm Bureau Federation, endorsed Wallace's efforts in 1922, but the farm leaders did not work hard enough to satisfy him. They feared public embarrassment, he reported, if the weather turned bad and food became scarce, a foolish fear in his view, for statistics indicated that low prices were a much more likely possibility. With farm organizations and journals failing to function as he thought the situation demanded, most farmers ignored his advice. ${ }^{42}$

Wallace's chief rival, the Iowa Homestead, proved to be an especially troublesome foe. He lashed out at "a certain farm paper" for its opposition. "Even the Iowa Homestead, supposedly a farm

41. Ibid., 8 April, 9, 29 September, 25 November, 16 December 1921, 3 February, 22 September 1922.

42. Ibid., 1 July, 2, 9, 16 December 1921, 20, 27 January, 24 March, 7 April, 28 July, 4 August, 27 October 1922, 12 January 1923; Evans, Prairie Farmer, 140-41; Shideler, Farm Crisis, 86-88. 
paper, is apparently shocked at the idea of reducing corn acreage." $\mathrm{He}$ argued that instead of criticizing the proposal, such critics should attack U.S. Steel. The Homestead's opposition, in his view, was "largely due to the fact that Wallaces' Farmer was in favor of it." Its opposition seemed very damaging, for the magazine circulated in Iowa, the state that most needed the program. He urged his competitor to "consider the proposition from the welfare of Iowa" and remember that this was "no longer only a Wallaces' Farmer program." While most farm papers were neutral on the issue, the Homestead, he complained, was "as distinctly hostile to the plan as the Price Current Grain Reporter and the Wall Street Journal." 43

The results of the battle over corn production were not totally disappointing. The low prices that followed the large harvest of 1921 generated more interest in 1922; corn production was down that year, especially in Iowa, Illinois, and Missouri. Corn prices rose the following year, although remaining well below the level he sought. ${ }^{44}$ He gave his paper some of the credit. ${ }^{45}$ But even though the buying power of corn remained well below his goal, he did not repeat the experiment in 1923 . He continued to regard reduced corn acreage as more intelligent and humane than the migration method and a necessary response to the power and behavior of organized urban groups, but he now encouraged those who had participated in the campaign and had enriched their soil by doing so to increase their corn acreage in 1923 and take advantage of the higher prices. ${ }^{46}$

Wallace concluded that greater success depended on a change in the rural social structure as well as bolder action by farm organizations. The people who participated were what he called, for this purpose, "independent farmers." They owned their own land and were not heavily mortgaged and thus were not controlled by landlords and creditors. They were freer to ad1922

43. Wallaces' Farmer, 13 May, 28 October, 9 December 1921, 4 August

44. Shideler, Farm Crisis, 189-91, 280-81; Wallaces' Farmer, 9 September 1921, 17 November, 1 December 1922, 12 January, 2 February 1923.

45. Wallaces' Farmer, 1 December 1922, 9 March 1923.

46. Ibid., 27 October, 17 November, 1, 15 December 1922, 5 January, 9 March 1923. 
just production than other farmers were, and they were more easily organized. Also, they saw that reduction "would mean that they would have to hire less outside labor." But they were only a minority of Iowa's farmers; if they became more numerous, then a production control program would have a better chance. ${ }^{47}$ Farm organizations and leaders also needed to change. If they made real efforts, they could persuade "great numbers of farmers" to cooperate. For now, however, it seemed that Corn Belt farmers as a whole did not "care to take any organized action" concerning the situation, and the farm movement was not ready to do what he believed must be done. ${ }^{48}$

The farm situation had improved but not nearly enough, according to Wallace's analysis. Farm prices in general were higher than they had been in 1922 and prices of urban products were lower, but the prewar relationship had not been reestablished. "What," the editor asked, "can we do now in order to put our corn and hog business in as prosperous a condition as it was from 1900 to $1914 ?^{n 49}$

Wallace CONTINUED to recommend production planning. ${ }^{50}$ By late 1923, however, he had become an advocate of what he regarded as a complementary plan. It had originated with George N. Peek, an Illinois farm implements manufacturer, and was embodied by 1924 in the McNary-Haugen bills. Wallace had been introduced to the plan at the National Agricultural Conference early in 1922. Within a year he began to express interest, and after his father came out for the plan, $\mathrm{H}$. A. also did so, labeling it "the only plan now in sight that means immediate relief for the wheat and hog farmer." He added, "Whether it will win out in congress this winter depends very largely on how urgently farmers insist upon its adoption." To help the cause along, he gave it strong editorial endorsement at the end of 1923 and early in $1924 .^{51}$

47. Ibid., 12 January, 19 October 1923.

48. Ibid., 13 April 1923.

49. Ibid., 1 June 1923. See also ibid., 11 May, 1 June, 26 October, 16,30 November 1923.

50. Ibid., 28 September, 5 October 1923, 11 January 1924.

51. Fite, Peek, 46; Winters, Wallace, 153-55, 253-57; Wallaces' Farmer, 12 January, 15 June, 2, 23, 30 November 1923, 4, 11 January, 8, 29 February 1924. 
Secretary Wallace's decision appears to have exerted a large influence on the editor's swing to support for the plan. H. C. had moved slowly to endorsement, reluctant to have the federal government play such a large role in the agricultural system. A moderately progressive Republican, he distrusted radicals as well as conservatives, opposed reliance on either "trust busting" or government ownership, and preferred government regulation of the economy, especially such segments as railroads, meat packing, stockyards, and the grain trade. He believed farmers would benefit from such government regulation and also from improved credit facilities, a high protective tariff for farm products, exemption of cooperatives from antitrust laws, and government stimulation of exports. He emphasized measures such as these during his early years as secretary of agriculture and also supplied farmers with a new agency, the Bureau of Agricultural Economics, to give them essential economic information, analyses, and forecasts. The agency would, he hoped, enable farmers to function on equal terms with other groups in the economy and persuade them to adjust their production to get better prices. ${ }^{52}$

These programs failed to bring the improvements in the farm economy that Wallace had anticipated, and although he had refused to endorse the Peek plan when he first heard about it early in 1922, he now concluded that conditions forced him to accept the plan. So he announced his endorsement on September 25, 1923. His biographer sees this as a very significant change in Wallace: a shift to the "left," "a compromise of his basic philosophy regarding the relation of government to the economy." The biographer adds, "Conditions forced him . . . to pursue a goal that would have sacrificed a degree of freedom for farmers in return for the survival and security of American agriculture." 53

After $\mathrm{H}$. A. endorsed the plan, he presented it as compatible with his own. It did make significant use of his work on price ratios. ${ }^{54}$ Furthermore, it seemed to offer a way of encouraging farmers to cut production of certain crops. Seeing harmony between the two plans, he argued, "Regulation of production will put the farmer on his feet again in a few years, if farmers accept

52. Winters, Wallace, especially chaps. 5, 6, and 9.

53. Ibid., 253-54, 256-60, 283-85.

54. Wallace, Oral History, 129-30. 
the principle wholeheartedly. Regulation of production, coupled with a government export corporation [as proposed in Peek's plan], will put him on his feet in the next six months." 55

Here also was another proposal to bring the behavior of farmers into harmony with that of urban business people. McNary-Haugen, Wallace explained, "would permit the farmer to sell on a protected market, just as the manufacturer sells on a protected market." 56 What he meant was that the plan would guarantee that the tariff protected the American farmer in the American market just as it protected the manufacturer. In other words, the scheme rejected proposals to take tariff protection away from manufacturers.

Despite the links between H. A.'s ideas and the Peek or McNary-Haugen plan, his endorsement of the plan represented a significant departure for him. For one thing, it would not sever the connection between Europe and the American farm. "Europe really needs our surplus wheat and pork, even tho [sic] she cannot afford to pay much for this food," he now observed. ${ }^{57}$ Even more significantly, the plan involved action by the federal government-large-scale action. Peek advocated the establishment of a government corporation, financed by a fee imposed on participating farmers, that would buy specified commodities at prices based on prewar standards (well above current prices) and "dump" them in Europe at prices Europeans could afford. The assumption was that this would prevent the surplus from depressing the home market. As Wallace summed up, "The only effective way we can use the European market for American farm products during the next ten years is by means of an agricultural export corporation of the type which can sell our surplus at one price abroad while at the same time a much higher price is being charged the American consumers at home. ${ }^{n 8}$

Furthermore, Wallace now began to talk about checking the migration of farmers to the city, an old agrarian theme. ${ }^{59} \mathrm{He}$

55. Wallaces' Farmer, 11 January 1924. See also ibid., 2, 23 November 1923.

56. Ibid., 23 November 1923.

57. Ibid., 2, 30 November 1923.

58. Ibid., 4 January 1924. See also ibid., 2, 30 November 1923.

59. Writing several years ago, I noted the importance of this theme in 
warned that if "natural economic laws" were "allowed to take their course ... several hundred thousand of the less efficient wheat and hog farmers" would be "eliminated during the next five years" with a "vast amount of discontent and hard feeling." Later, the United States would discover that its population had increased to a point where it would be necessary "to put the less efficient hog and wheat farmers ... back to work to produce enough to feed our people." The process struck him as "a great waste." By holding people on the land, the new plan would avoid that waste. ${ }^{60} \mathrm{He}$ did not foresee that developments in agricultural science and technology, including the perfection and acceptance of hybrid corn, would soon make it possible for a very small population to serve the nation's need for food.

Wallace's thinking, influenced by intellectual change in his father as well as by economic realities, had taken a turn. Still rejecting what he regarded as radical solutions that attacked big business organizations and government programs that benefited them, H. A. now concluded that farmers-very important people in his view-must have more help from the federal government. He had not discarded his belief in production adjustments, itself a departure from past practices, but he was disappointed with the results of his campaign for cuts in corn production and believed more must be done to raise farm prices. They had, to be sure, already gone up some from the low level of 1921. At least the price of Iowa's main crop, corn, had. But his statistics suggested that this was not enough and that tough times still lay ahead unless the government, as well as farm organizations and farmers themselves, acted effectively. As he viewed farming, it was a business operating in an economic system in which key urban groups were already well organized, and he believed that the farm business must also organize, but his experience as an advocate of organized behavior persuaded him that the process was not going forward fast enough, so a government export corporation must also be formed. His advo-

Wallace's thinking as editor, but I did not really recognize then that it did not become important to him until after he became a champion of the Peek/ McNary-Haugen plan. See "Mind of a Farm Leader," 150-51; "Corn Huskers and Master Farmers: Henry A. Wallace and the Merchandising of Iowa Agriculture," Palimpsest 65 (May/June 1984), 85, 87, 88, 90.

60. Wallaces' Farmer, 30 November 1923. 
cacy of government action to raise farm prices anticipated ways in which the New Deal would reshape the agricultural system. ${ }^{61}$

Wallace's thought in the early 1920s anticipated the New Deal for agriculture in yet another way, one that emerges clearly when comparisons are made with James. Baird Weaver and Smith Wildman Brookhart. They, especially Brookhart, represented the radicalism that Wallace feared. The farm editor, although by no means happy with the leadership of Herbert Hoover and other men at the top in the 1920s, did fit into the New Era more comfortably than the senator did. Unlike Brookhart, Wallace did not believe that the power of the corporations was the problem, however much he might have preferred a more decentralized economic system. He believed that if farmers organized and had certain types of help from government, they could survive and prosper in a system that included large business and labor organizations. Farmers could, in other words, become part of the new order; they need not rebel against it. Thus, Wallace brought to the New Deal not only a quite positive attitude toward the role of the federal government in agriculture but also a hostility toward radicalism that was also an important component of the New Deal. That political movement and governmental program was an antirevolutionary response to a situation with revolutionary potential as well as a significant stage in a long-term, large-scale transformation of American capitalism and a major contributor to the development of an economic system dominated by the interplay among large public and private organizations. ${ }^{62}$

61. See Richard S. Kirkendall, "The New Deal and Agriculture," in John Braeman et al., The New Deal, 2 vols. (Columbus, 1975), 1: 83-109.

62. See Richard S. Kirkendall, The United States, 1929-1945: Years of Crisis and Change (New York, 1974), especially chap. 13; and idem, "The New Deal and American Politics," in Harvard Sitkoff, ed., Fifty Years Later: The New Deal Evaluated (New York, 1985), 11-36. 
Copyright of Annals of Iowa is the property of State of Iowa, by \& through the State Historical Society of Iowa and its content may not be copied or emailed to multiple sites or posted to a listserv without the copyright holder's express written permission. However, users may print, download, or email articles for individual use. 